\title{
Library Services to Inmates in the Rural County Jails of Western North Carolina
}

This paper investigates the current status of library collections and services in the rural jails of western North Carolina. The authors interviewed sheriffs and jail administrators in 6 of the 7 westernmost county detention centers. This paper discusses the benefits of reading and the importance of literacy to this underserved population, presents descriptions of the collections and library service policies along with photographs of actual book collections, and explains the challenges the jails face in maintaining and delivering these services. The authors interviewed sheriffs and jail administrators in 6 of the 7 westernmost county detention centers. This paper discusses the benefits of reading and the importance of literacy to this underserved population, presents descriptions of the collections and library service policies along with photographs of actual book collections, and explains the challenges the jails face in maintaining and delivering these services. The authors argue that one possible solution to these challenges is to build partnerships between public library systems and their local jails in a manner that benefits everyone in the community.

$\mathrm{N}$ orth Carolina libraries strive to serve all citizens regardless of need or circumstance. However, this begs the question of whether and to what extent it is a public library's mission to provide library services to the incarcerated in their service area. This underserved resident population within the community is very challenging to take on as an outreach service for any public library. While most North Carolina State Prisons, under the Department of Corrections, have at least rudimentary recreational and legal library collections and services, the same is not the case in jail and detention centers, particularly in rural jails. Services to rural jail populations are often delivered by the jails themselves. While it is to be expected that they suffer from inadequate library collections and services due to the distinctive characteristics of those institutions (e.g. inadequate staffing, limited local budgets and space, etc.), very little is known about their library services except by those who are in direct personal contact with them.
Jails, unlike prisons, confine individuals awaiting trial, convicted prisoners awaiting transfer to prison, and other offenders typically serving a sentence of less than one year. The short-term period of the inmate's confinement in jail and the high rate of turnover limit the amount of long term educational and selfimprovement programs that can be effectively offered (Applegate \& Sitren 2008, De la Peña 2004). In addition, to provide what we think of as regular book lending services to these inmates would be very limited or infeasible due to the expense, high level of destruction and loss of materials, and the high rate of turnover among jail library users. Thus, the lending services that are offered in jails are usually short term in nature, such as weekly or monthly access to a book cart. However, regardless of the length of an inmate's stay, access to these materials can be very important to the inmate.

Another institutional challenge for library services is the high level of custody in most jail environments.
The classification policies in jails are much less discrete than in prisons and serious offenders are frequently housed with lower level offenders. The intermingling of hard time convicts, detainees, inmates with mental illnesses, drug users, violent offenders, and others requires a higher level of custody and more direct supervision by officers (Clark \& MacCreaigh 2006). The need for a constant high level of security can limit access to library services and collections because there simply are not enough officers to facilitate even minimum access.

Library collections and services for jail inmates are impacted by the funding structure of jail facilities. Similar to public libraries, jails are funded by the tax revenues of their counties. Rural jails located in economically distressed counties suffer from a corresponding lack of funding for inmate education and enhancement programs. In addition, research on priorities and needs of jails in rural settings have ranked such things as physical plant maintenance, personnel, and medical care for inmates 
as budget priorities. Library material or education programs were not noted as a priority in this research (Ruddell \& Mays 2006; Stinchcomb \& McCampbell 2007).

To investigate the current status of library collections and services in rural jails provided to inmates, the researchers conducted face-to-face interviews with the sheriff and/or jail administrator in the six westernmost North Carolina counties. The interviews included questions about library services and collections, as well as the characteristics of the institutions and inmate populations. The actual book collections were examined at all the facilities. This paper will discuss the benefits of reading and the importance of literacy for inmates, and describe the collections and library service policies of six of these rural North Carolina jails. It discusses the challenges the jails face in maintaining and delivering library collections and services. And finally, it proposes that one possible solution to this situation is working towards building partnerships between the public library systems and their local jails in a way that benefits everyone in the community. This research was inspired by the effort of the regional comprehensive university, Western Carolina University, to expand its mission to engage with the community in regional cooperative ventures in the spirit of Ernest Boyer's concept of the scholarship of application, and on the part of the authors to engage in crossdiscipline collaborations between the Library and Criminal Justice department.

\section{Literature Review}

\section{Benefits of Reading and Importance of Inmate Literacy}

Most of those reading this article might not have ever taken the time to actually question what are the real value and benefits of the quiet solitary activity of reading. As librarians, professors, or professionals, we take the benefits of reading for granted. We have access to an unlimited numbers of items and type of materials; and we might even find it quite an attractive prospect to have nothing but time to read all day if we were incarcerated. However, we found that the library services provided in the jail situation are not what you might imagine should you find yourself unfortunate enough to be there.

There are many real benefits and values that reading can and does give. These are especially true for those who are incarcerated. Reading is reformative and helps develop critical thinking skills (Jordet 2008). Besides the individual benefits of structuring time, relieving boredom, and learning about previously unknown topics, reading has many pro-social benefits to consider. "Reading is an irreplaceable activity in developing productive and active adults as well as healthy communities. Whatever the benefits of newer electronic media, they provide no measurable substitute for the intellectual and personal development initiated and sustained by frequent reading." (National Endowment for the Arts, 2007). Even for those in jail for a short time, the personal development benefits mentioned in this report can include such things as vocabulary building, challenging self-concepts, encouraging self-reflection and introducing social context of choices and reaction as well as general social awareness they might not have experienced in the past. (Jordet 2008)

But these benefits can only be realized if they are literate. The disparity in reading proficiency rates between incarcerated and non-incarcerated Americans is significant and growing, with the percent of prison- ers reading below Basic level at 56\% (National Endowment for the Arts, 2007). There is also a large disparity in terms of learning differences, with adult prisoners being more likely to have been diagnosed with some type of learning disability (Greenberg 2007, Crayton 2008). While current data for jail inmates' education levels and literacy rates is limited, the statistics from 2003 show that over a third of jail inmates have most likely dropped out of school compared to 1 in 6 in the general population. Jail inmates are also less likely to have completed high school or the equivalent educational attainment with $47 \%$ of jail inmates having failed compared to $18 \%$ of the general population (Harlow 2003). All these factors can make it a challenge for the incarcerated to take advantage of opportunities to hone their skills since they are already at a disadvantage because of their lack of abilities.

We know that the best way to increase literacy is to read extensively and recreationally (National Endowment for the Arts 2007). It does not really matter what one reads because reading anything teaches reading. But, to encourage low-literacy readers to continue to read and increase their literacy there need to be materials available that they really want to read. The kinds of materials that are available for a struggling reader can encourage or discourage their motivation to increase their literacy. Therefore, the selection of materials for inmates needs to be done carefully and thoughtfully if those materials are to benefit the life-long learning that literacy makes possible (Clark \& MacCreaigh 2006).

\section{The Role of Library Services}

Although the library literature in recent years has not focused much on the role of library services to jail pop- 
ulations, those that have written on the topic in the past, especially in the 1970-80s, have helped to identify values and policies later adopted by ALA and the Association of Specialized and Cooperative Library Agencies to assist public libraries in providing these outreach services. (McCook, 2004) The history of reading as a primary reformation tool has a long history and librarians have sought to expand and extend this role in the jails and prisons (Sullivan 2000). Rubin and House (1983) used a three part rationale/imperatives for providing library services to jail inmates. Their first rationale is the humane; that inmates need these services perhaps more than the rest of the population. The next relates to the professional; that there is no doubt that these services should be provided in jails. And lastly, their rational is about the legal; that there are standards of service in the library profession, in some states, and internationally as well as what needs to be provided legally. Clark and MacCreaigh (2006) identified the importance of these services to inmates, including providing a measure of civilized normalcy and familiarity, the opportunity for learning, and demonstrated security benefits.

\section{Methods}

This study focuses on the rural Western North Carolina (WNC) counties of Cherokee, Clay, Graham, Haywood, Jackson, and Macon. Swain County Detention Center in WNC declined to participate. All of these counties were designated as rural by the U.S. (U.S. Census, 2010). The jails in these counties are small and are in predominately rural settings with small towns. To the outside observer, these jails seem quite similar to one another in character and function. According to the North Carolina Detention Facility Directory and
Resource Guide (2012) all of these facilities have $8-150$ beds.

After Institutional Review Board (IRB) approval, introductory letters were sent to the sheriff of each county before being followed up by a phone call to schedule the onsite interview. Questions were asked covering six general areas with follow up questions. (See Appendix A) The structured interviews were conducted over three weeks during the summer of 2012 and lasted approximately 1 hour. Both investigators were present during the interviews and written notes were taken of the answers. Both investigators were also given an intensive tour of the jail facilities and photographs of the book collections were allowed to be taken.

\section{Discovery}

\section{The Role of Library Services}

In the interviews, when asked about the role of library services in their jail and why it was important, jail officials mostly commented on the positive outcomes of these services. These comments could be categorized in three ways. First was that library service gave the inmates something to do to combat tedium with such comments as "it gives them something to do because boredom is a problem"; "It gives the inmates something productive to do" and inmates "need a little something." The next theme in the answers was about the benefits to the jail. These answers were with such comments as "a happy inmate is a safe inmate"; "allows and gives inmates control and respect"; and "a happy inmate with something to do in a positive way is a benefit to us."

But perhaps the most significant theme concerning the role of jail library collections was the view among all the officials we interviewed that access to books was a right that the inmates had and not a privilege that might be taken away as punishment. Thoughts about access to reading materials being a valued right of the inmates are reflected in comments such as "the role of the jail was custody and care and not punishment" and "anything that enriches and enhances the inmates' experience is a benefit."

\section{The Collections}

During the facility tours all of the library collections were examined. The items, mostly books, could be borrowed by inmates and read in their cells and living areas. The books were mostly in paperback format. Any hardback books that these jails had could be used only in that area. No hardback books were allowed back into inmates' living areas because of the risk of inmates' using the physical materials of the cover for destructive purposes. While some jails allowed magazines and newspapers in the inmates' common areas, they were not part of the regular collection. Several of the jails did not allow magazines and newspapers for the same reason they prohibited hardback books.

The types of books in the jail collections examined were very limited. The genres of the paperback book collections were mostly fiction; predominately romance novels, some general popular fiction, and a few young adult titles. There were very few nonfiction or self-help books, although there were some in each collection. The larger jails at Haywood (HCDC \#1) and Cherokee (ChCDC \#1 -3) did have entire rooms set aside for book collections that the inmates could go to and make book selections. The slightly smaller facility in Clay County (CCDC \#1-3) had a room assigned solely for the library collection. We saw no evidence that inmates were allowed in this room. The Haywood, Cherokee and Clay 
County collections, unlike those in the smaller jails, did have some specialized sections that helped to organize the collection. In one of the libraries, at least a third of the shelf space was taken up with many copies of the Bible (ChCD \#2, left shelf and

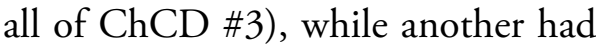
a small legal section (HCDC \#4), and several had leftovers from a previously discontinued GED class that included some general study guides.

The general makeup of the materials was similar to what one might see at a local thrift store with leftovers, older and unknown authors and titles, duplicates of currently popular titles (for example, we saw several copies of the Twilight series in one of the collections), and a general hodgepodge of cast-off books. Only two collections, Clay and Macon County, seemed to put any effort into selecting a wide range of fiction genres. The researchers were not able to examine all of Macon County's collections, only those on the book cart, because most of the materials were in boxes due to lack of shelf space (MCDC \#2). Jail officials were somewhat concerned about the "appropriateness" of the titles to a jailed population. One sheriff mentioned that overly sexual material was prohibited because it might arouse inmates and lead to sexual misconduct. There was a passing comment that crime literature was also not allowed for obvious reasons. But there was little evidence that the jailers or others beside the inmates actually pre-read any materials, although at least one sheriff identified himself as being an "avid reader."

As mentioned, the two larger jails in Cherokee and Haywood had rooms designated for library collections. These multipurpose rooms also served as the chapel, video conferencing room, and/or classroom. One of these larger jails additionally had a book truck that allowed the jailers to deliver books to those that could not visit the area. (HCDC \#2) The only rural jail that had a room solely designated for library services was Clay County. While the Clay County jail library was about the size of a large closet, it seemed crammed with books and other materials including a large selection of videos and puzzles. (CCDC \# 1, left shelf) It was also unusual as compared to the other jails in this study in that it had an inmate checkout system with several rolling book trucks with books that had unique identification numbers on them and a card system for checking out books to the inmates. Of the other three jails, two used a twotiered grey industrial wheeled cart as a rolling book collection (MCDC \#1 and JCDC \#1). Two jails had rolling shelf carts (CCDC \#2 and HCDC \#2 ). In Jackson, this rolling collection was the entire collection; in Macon, it was backed up with two boxes of books in the corner. And finally, in Graham, there was no space for a shelf or book cart; the book collection was in a bottom locker in the corner storeroom full of about 30 books. (GCDC \#1) The actual titles could not be seen except for the Bible that was on top of the closer of the two stacks in the locker.

When asked how library materials were acquired, all the jails' officials mentioned donations and items brought into the jail from friends and families of inmates, a few mentioned staff making personal donations from thrift stores and yard sales, and some mentioned previous donations from friends of the library groups in the distant past. None of the jails' administrators mentioned having any kind of a budget for reading materials for the inmates. When budgets were discussed at all, it was about the high cost of providing basic health care to the inmates and how these costs have exploded making any other expenditure almost impossible to afford.

When asked if inmates could get their own reading materials sent to them directly from a publisher, most would allow this, although it did not happen often. Those that did allow it seemed to favor requiring that once they were done with reading the material that the inmate make the item a "donation" to the general book collection of the jail. Only one jail allowed the inmates to keep their purchased books in their personal possessions, outside the cell, returned to them after they were released. Other jailers mentioned that they have had bad experiences with this practice such as receiving bills once the inmate was released. Consequently, they no longer allow this practice.

\section{Administrative and Operations Procedures}

The loan rules were basically the same for all the jail libraries. Half of the jails allowed inmates to have three books at a time in their cells. Of the rest, one allowed four and one only two. The smallest jail, with only a small locker of books, did not mention their book lending policy. For all the jails, the Bible did not seem to count as one of the books and several mentioned the maximum number "plus the Bible." However, because of the shared nature of many of the cell blocks, these numbers were only important to those confined in a single cell. Most of the jails had shared community space where the inmates could and did trade books between times they were allowed access to the collection or book cart. One jail had several small book shelves in the common area where the book collection was neatly shelved together for easy access by everyone in that block. Several other jails had books stacked ran- 
domly under the shared telephone. The average time before an inmate could check out different books was about once a week but several of the jails allowed inmates who read more quickly to return them and get more when they needed them.

\section{Major Issues, Challenges and Limitations}

Over the course of the interviews, the major issues and challenges for rural jail libraries were evident. First, the general state of the book collections could be described as damaged and distressed. Many of the paperbacks were torn, damaged and missing covers (see HCDC \#3 for examples). In one of the jails, they mentioned that inmates have been known to write messages between the cell blocks to each other in the margins. In addition to prohibited communications jail officials were concerned that the inmates would hoard books if limits placed on the number of items that could be check out at any one time were increased. Second, there is little variety among all of the collections. For example, there was a lack of nonfiction titles on issues that might be of interest to an inmate's educational or self- help pursuits. The researchers were surprised not to see any titles on topics such as mental and physical health, quality of life issues such as personal finances or job skills, or even self-help in subjects such as avoiding violence, drug and physical abuse, or dealing with divorce that might be of benefit to this population.

The limitations of space, shelving and budget were also identified as problems, especially for these smaller rural jails. Space and budgeting issues impacted not only the state of the book collection and its currency, but the possibility of extending library service to different populations within the jail. When asked, jail administrators said they did not have means to address any special needs for groups such as low literacy inmates, Spanish speakers or the visually impaired, despite the fact that statistically, there is likely a great need for these types of items. The jail officials did not feel the need for any of these types of materials. In about half of the jails included in this study, simply having some materials that were readable for the general population's reading needs posed a significant challenge.

In addition to problems posed by the physical state of the collections, space considerations, and budgetary limitations, rural jails are also confronted with requests from inmates to provide legal materials. Jail officials expressed different opinions about their responsibility under the law in providing any kind of law books and legal services. One jail administrator told us state law required it while others expressed that it was solely the responsibility of the inmate's lawyer. However, overwhelmingly, these jails' officials relied upon the inmate's lawyer or legal aid to support any legal requests, although a few mentioned that inmates could request photocopies of specific legal materials or be taken to the county law library upon request.

\section{Jail Attitudes Towards \\ Expanding These Services}

During the course of the interviews, the jail officials were asked if they had contacted the public library in their county about helping them provide library materials to the inmates and if they were interested in working with them in the future to expand their library services. None had worked with county library systems directly, but although guarded, all expressed a positive outlook about future possibilities and the expansion of services.
There was some concern that managing such a relationship might take more time and staff resources than they had available. Many mentioned space limitations for expanding the number of books beyond what they already had. Several mentioned that the jails had worked with various friends of the library groups and other civic groups to get donations in the past, although for all of them that had happened long ago. Overall, all of the jail officials interviewed expressed interest in exploring the possibilities with public libraries in their respective counties.

\section{Summary}

The photographs of the current collections available to the inmates in these rural jails shown in the appendix can tell the story all by themselves. As the researchers look deeper, it is very evident that these rural county jails face enormous challenges in providing even rudimentary library services to inmates. The most significant challenge faced by these rural jails is the lack of any funds for purchasing materials. Another considerable challenge is the limited space available for materials and many cannot provide any more than a single movable book cart full of books. And finally, these jails have limited staff, which makes it impossible to manage anything beyond a bare necessity of providing something, anything for the inmates to read to pass the time.

Considering the jails' collecting method, the current collections surveyed seemed to be of questionable intellectual quality to meet more than the minimal reading needs of the population they serve. Although the role of providing reading material is a vital part of the jail culture, little time, energy or resources are available from the jailers or jail administrations to actively collect quality 
targeted items for the distinct needs of their residents. All these challenges coupled with the tendency of these rural jails to work in isolation seems to prevent them from exploring the possibilities of working with their local public libraries.

The most specific need identified by this research is for current fiction and more non-fiction paperbacks on subjects that encourage reading such as educational, life enrichment, literacy, resources for job seeking, and general intellectual stimulation that might be of interest to those who are incarcerated. These types of items are not subjects that are likely to be donated or readily available, so they must be collected deliberately at a cost. Although the researchers did not have the time to assess the reading levels within these collections, there was a general impression that not many of the materials are appropriate for low-literacy level readers. In addition, they also see a need for materials on such topics as reentry into society after being jailed, mental and physical health, life enrichment, and self-education. With inmates having to serve up to two years in these county jails, they have time on their hands to engage and improve their lives, if given the chance.

In general, the book collections currently provided in the rural jail environment in WNC are inadequate in numbers, topics, and currency. The environment and uniqueness of this underserved community population makes these collections extremely important and they are in great need of attention and resources. These collections could do so much more to provide much needed opportunities to enhance the lives of these citizens and help them to use their time in jail more productively. If we value reading and literacy and recognize the importance of reading for a healthy community, we owe it to ourselves to provide these citizens with more substantial reading materials than these jails currently provide.

\section{Future Directions for this Research}

During the beginning stages of this research project, there appeared to be several resources and services already available for addressing the challenges faced by these jails if some connection could be established between them and their local public library systems. The researchers spoke with the head librarians at all three of the local library systems (Nantahala Regional Library System, Haywood Public Library and Fontana Regional Library System) to gauge their level of interest in working with the jails to address the needs identified in this article. Deposit collections, targeted donations, and regular access to the local library friends and other civic groups all seemed to be possible solutions and not out of the range of possibility. But we worried also, that a one-time influx of monies or attention would not be enough. Regular attention and ongoing cooperation is needed. However, similar to the situation faced by the rural jails, budget and personnel limitations are also issues for public libraries. At this time, Fontana Regional Library System has agreed to begin working with the authors to look at grant possibilities to serve rural jail library collections with projects such as creating a targeted bibliography of paperback book titles that might be of interest to outside funding groups. This outreach endeavor by this public library system could be a great benefit to this previously underserved group of their county residents, and can serve as a working model for other rural library systems in North Carolina. There is hope that a partnership between the
Fontana Regional Library System, the researchers at Western Carolina University and the local sheriffs department will be able to attract some continuing funding sources for this project.

The work is ongoing.

\section{References}

Applegate, B.K. \& Sitren, A.H. (2008). The jail and the community: Comparing jails in rural and urban contexts. The Prison Journal, 88, 252-269.

Clark, S. \& MacCreaigh, E. (2006). Library services to the incarcerated: applying the public library model in correctional facility libraries. Westport, CT: Libraries Unlimited.

Crayton, Ann \& Neusteter, Suzanne Rebecca. (2008). The Current State of Correctional Education. Commissioned papers from the reentry Roundtable on Education of the Urban institute. Retrieved December 5, 2012 from http:// www.urban.org/projects/reentryroundtable/roundtable10.cfm De la Peña McCook, Kathleen. (2004). Public Libraries and People in Jail. Reference \& User Services Quarterly, 44, 26-30. Greenberg, E., Dunleavy, E., \& Kutner, M. (2007). Literacy behind bars: Results from the 2003 National Assessment of Adult Literacy Prison Survey. Washington, DC: National Center for Education Statistics. Retrieved Dec 5, 2012 from http://nces.ed.gov/ pubs2007/2007473.pdf

Harlow, C.W. (2003). Education and correctional populations. Bureau of Justice Statistics. NCJ 195670. Retrieved December 5, 2012 from http://a.parsons. edu/ -lewic830/images/Ecation- 
alandCorrectionalPopulations.pdf Jordet, Judith. (2008) Reading and prison libraries. Corrections.com Retrieved December 5, 2012 from http://www.corrections.com/articles/19578

LIS Incorporated. (2001). NIC research on small jail issues: Summary of findings. Longmont, CO: National Institute of Corrections. National Endowment for the Arts. (2007) To read or not to read : a question of national consequence. Research Report ; \#47. Washington, DC. Retrieved December 5, 2012 from http://www.nea.gov/
research/ToRead_ExecSum.pdf

North Carolina Jail Administrators' Association. (2012) North Carolina Detention Facility Directory and Resource Guide 2012. Retrieved December 10, 2012 from http://www.ncjaa.org/wp-content/ uploads/2012/09/NCJAAHandbookMay2012.pdf

Rubin, R.J. \& House, C. (1983). Library service in US jails: Issues, questions, trends. Library Journal , 108 173-177.

Ruddell, R. \& Mays G.L. (2006). Expand or expire: Jails in rural America. Corrections Compen- dium, 31, 1-27.

Stinchcomb, J.B. \& McCampbell, S.W. (2007). Jail leaders speak: Current and future challenges to jail administration and operations. Naples, FL: Center for Innovative Policies.

Sullivan, L. E. (2000). The least of our brethren. American Libraries, 31, 56-58.

U.S. Census Bureau. (2010). Urban area thematic maps. Generated August 14, 2012, from http:// census.gov/geo/www/census/UA/ maps/US/UAUC/2010.html

\section{Appendix A: Questions to the WNC Sheriffs or Jail Administrators}

1. Would you tell us what you know about the history of Library Services to this institution?

2. What is the role of Library Services in the jail?

- Follow up question - Has there been any interest in expanding, limiting, or changing these services?

- Follow up question - With the new Justice Reinvestment Act, and with inmates staying in jail much longer, do you see any changes being made to Library Services in the future?

3. Where do you get your materials for Library Services?

- Follow up question - Where could you get materials in the future or where would be preferable?

4. What administrative or operational issues or concerns do you have had with providing library services to inmates?

- Follow up question - What benefits or positive outcomes have you seen with providing these services to inmates?

5. Do you tailor your services to different populations?

- Follow up question - How do you provide materials for low literacy, Spanish speaking, or other special needs inmates?

6. What do you do to support inmates with legal issues?

\section{Appendix 2: Photographs of the jail libraries}

\section{Haywood County Detention Center}

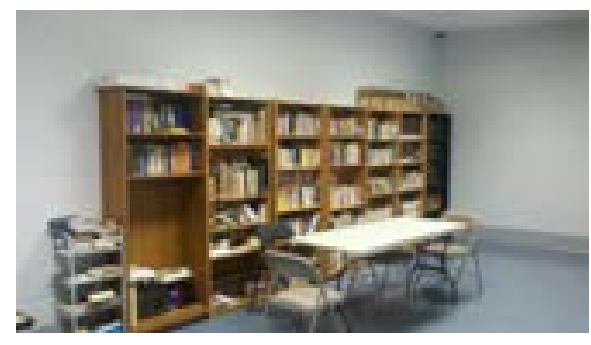

HCDC \#1 - Book shelves

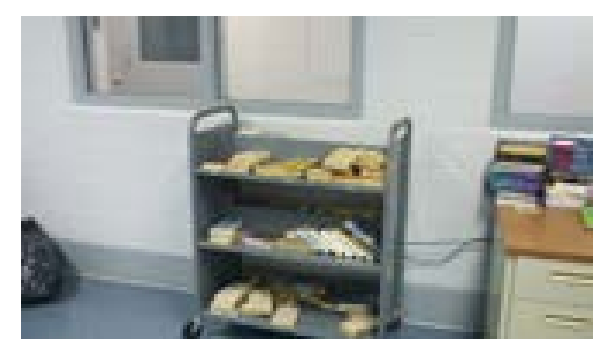

HCDC \#2 - Bookcart

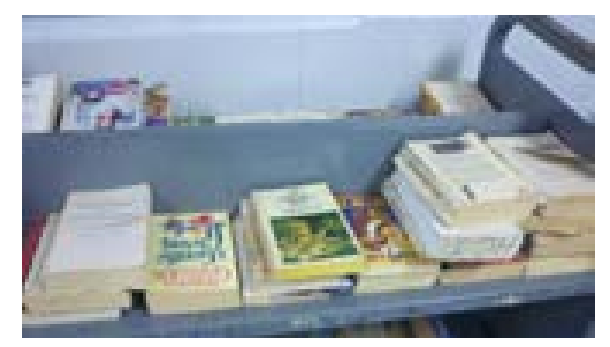

HCDC \#3 - Examples of the physical state of materials 


\section{Cherokee County Detention Center}

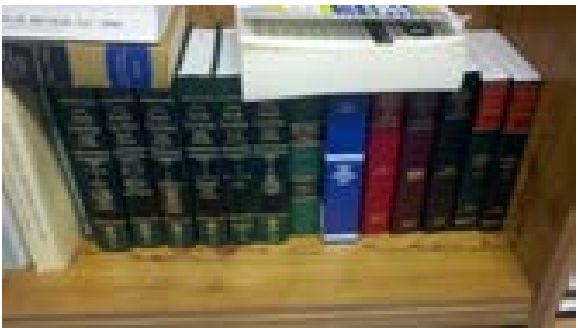

HCDC \#4 - Largest law book collection in the studyCherokee County Detention Center

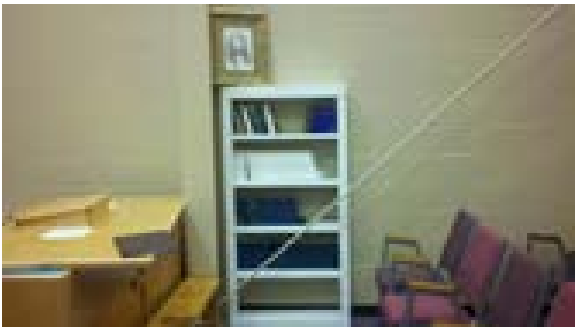

ChCDC \#3 - Third shelf, mostly Bibles

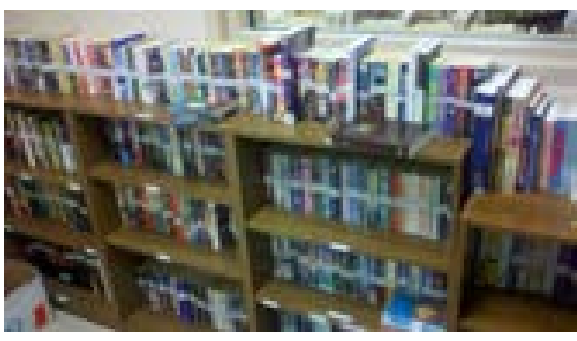

CCDC \#3 - Book shelves - notice call number tags on books

\section{Graham County Detention Center}

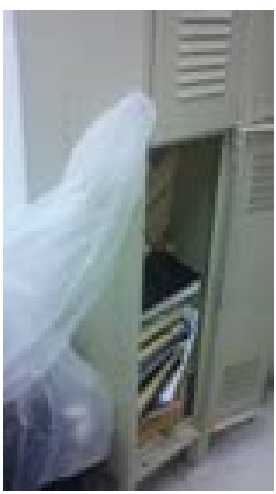

GCDC \#1 - Book locker

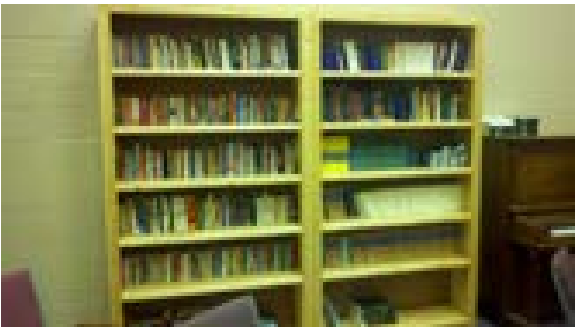

ChCDC \#1 - Biggest of the three book shelves - left side mostly Bibles

\section{Clay County Detention Center}

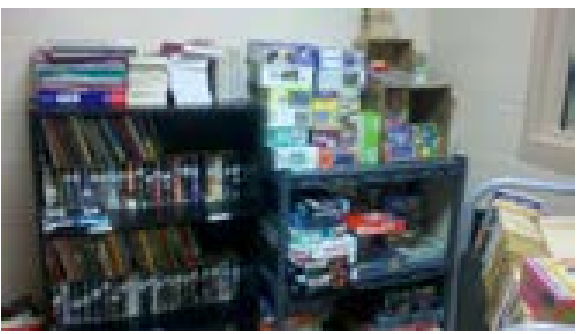

CCDC \#1 - Shelves that include nonpaperback formats

Macon County Detention Center

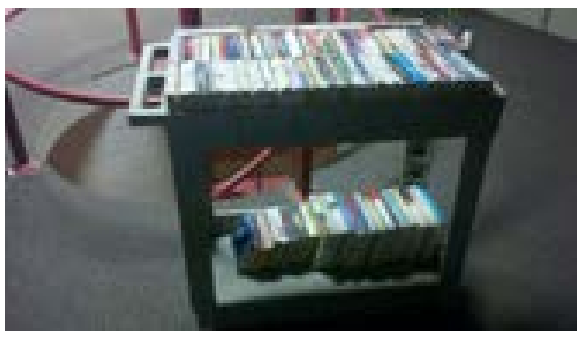

MCDC \#1 - The book cart

Jackson County Detention Center

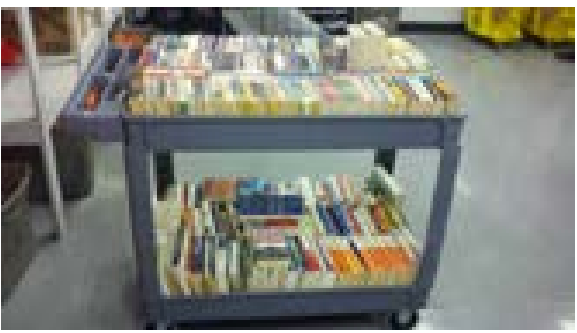

JCDC \#1 - Book cart

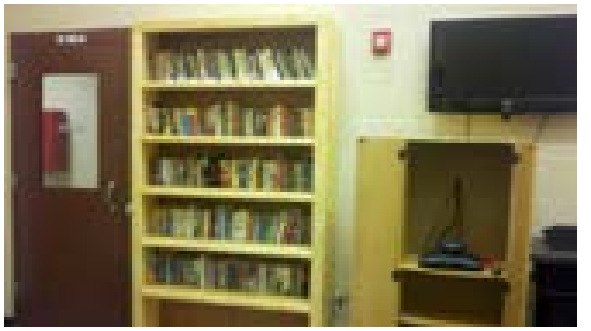

ChCDC \#2 - Second book shelf and video equipment

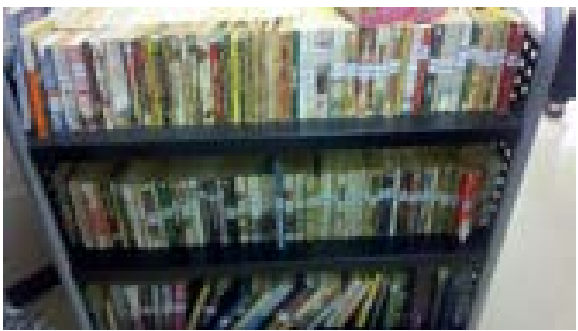

CCDC \#2 - Rolling book shelf

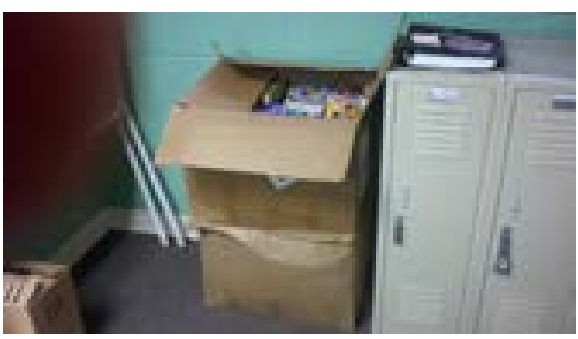

MCDC \#2 - Book boxes for overflow from book cart 